\title{
Oil and gas business in changing times
}

\author{
Sergiu BRASOVEANU \\ The Bucharest University of Economic Studies, Bucharest, Romania \\ sergiu.brasoveanu@gmail.com
}

\begin{abstract}
The top 5 oil majors (British Petroleum, ExxonMobil, Total, Chevron and Royal Dutch Shell) are analyzed in terms of investments, earnings and financial \& operational performance along the entire business value chain, for a period of 5 years. One of the key objectives is to understand how the Upstream and Downstream segments may play different roles in the definition of a winning corporate strategy, considering how they may reveal very different strengths and weaknesses during crude oil price crises. When the crude oil price goes down, the upstream sector is running big cost cutting measures, in order to reduce expenditures and keep acceptable gross margins per barrel of oil equivalent. On the other hand, the downstream segment receives cheaper raw material without a significant decrease in the final price of the oil products. Thus, how can oil companies leverage this flexibility in order to pass successfully through periods of crude oil price slides, and even take advantage of those? The paper aims to analyze the correlation between oil price and oil volume produced on one hand, and investments and earnings, split by business segments, on the other hand. The variation of investment and earnings is hence compared to crude oil price fluctuations for a clearer picture of the business profitability per segment during the peak and bottom periods of the oil market. Upstream and Downstream segments are also benchmarked against each other to understand the role that each of them is playing in the industry. The results are expected to provide some trend lines to understand how much the cost cutting measures are impacting the overall business, as well as to appreciate whether the reduction in the oil production, which in theory should be followed by a rise in prices, is indeed in the best interest of the oil majors. Going further into analysis, the paper is trying to define an optimum production interval, that will maximize profits along the entire value chain (upstream and downstream) of the oil business, defined by both the production volume of crude oil (replacement cost per barrel in accordance with volume), as well as the price per barrel of oil equivalent. The analysis takes into account official sources exclusively, i.e. oil companies' websites, corporate crude oil production reports, annual financial reports and investors' analyses.
\end{abstract}

Keywords: oil, supermajors, production, investments, earnings.

\section{Introduction}

The oil and gas industry has passed through difficult periods, twice in the last decade. The last crisis started with the crude oil price drop at the end of 2014 and reached the bottom in January 2016, when BRENT fell below $\$ 30$ /boe. The biggest publicly traded companies reported a big fall in terms of revenues, earnings and investments for this period. However, the volume of oil produced and traded on the market grew continuously.

This steady growth in produced volumes of oil established the following ranking of companies:

1. Gazprom (8.38 $\mathrm{M}$ boe/day) is the largest publicly traded energy producer in the world. The company is known primarily as a natural gas producer, accounting for 
nearly $13 \%$ of the world's total production. While Gazprom production is $86 \%$ natural gas, the Gazprom Neft subsidiary, is the company's primary oil production arm. Gazprom Neft would alone rank among the world's top 25 oil producers. Gazprom has an enterprise value (EV) of $\$ 84.3$ billion.

2. Rosneft (5.07 M boe/day) is the world largest publicly traded oil company. Rosneft has an enterprise value of $\$ 72.5$ billion.

PICBE | 10

3. ExxonMobil (4.1 $\mathrm{M}$ boe/day) has an EV of $\$ 390$ billion, being the highest among energy companies. It managed to grow its oil production by $13 \%$ in 2015 , but the decline in oil and gas prices caused their cash flow to decline from $\$ 208$ billion in 2014 to $\$ 78$ billion in 2015.

4. PetroChina (4.07 M boe/day) is a listed division of the state-owned China National Petroleum Corporation. Its $\$ 303$ billion EV is second only to ExxonMobil among publicly trading oil companies.

5. British Petroleum (3.24 M boe/day) is the largest European supermajor. The company suffered a net loss of $\$ 6.5$ billion in 2015 - the largest loss it has registered for at least three decades. BP only managed to add enough new oil reserves in 2015 to replace $61 \%$ of the oil produced for the year. BP's EV is $\$ 121$ billion, down from the $\sim \$ 200$ billion it had prior to the 2010 Gulf of Mexico oil spill.

6. Royal Dutch Shell (2.95 M boe/day) replaced less than $100 \%$ of its reserves for the year. Shell has an EV of $\$ 216$ billion - the third highest EV energy company in the world.

7. Chevron (2.62 M boe/day) managed to grow oil production by $2 \%$ in 2015 , while replacing $107 \%$ of its oil production. The company has an EV of $\$ 207$ billion.

8. Petrobras (2.55 M boe/day) increased the oil production by $4 \%$ in 2015 , having an EV of $\$ 132$ billion.

9. Lukoil (2.4 M boe/day) is Russia's third company among the Top 10 publicly traded oil and gas producers, with an EV of $\$ 36$ billion.

10. Total S.A. (2.35 M boe/day) has an EV of $\$ 136$ billion. (Helman, 2016)

Hereafter Rosneft, ExxonMobil, Shell, BP and Chevron are analyzed in terms of volumes of barrels of oil equivalent (boe) produced, earnings and capital expenditures VS oil price variation for the 2010 - 2015 period.

The above-presented values of volumes contain the total produced volume of oil and natural liquefied gas, as well as the volume of natural gas - converted in barrel of oil equivalent measure unit. Taking into account the break for price indexation of natural gas, the volumes presented forward do not contain the amount of natural gas produced.

\section{Rosneft}

Rosneft's evolution for the last 6 years is very specific. The biggest oil company (in terms of crude oil production in 2015) has its assets settled mainly in Russian Federation. The company follows the political decisions of the government and its economic output is under direct influence of these factors. 


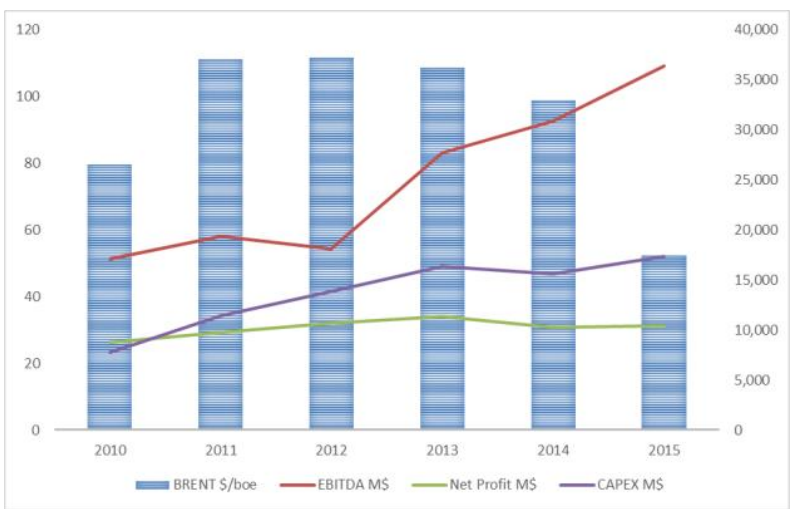

PICBE | 11

Figure 1: Main economic indicators vs Oil price

Source: Authors' own research results/contribution.

Despite the oil price drop registered between 2014 and 2015, the company investments and EBITDA are growing. This could be explained by the advantage taken by the company, due to rubble devaluation. Net profit remained flatted until 2013, because of the high investment rate and due to increased taxes for produced oil and gas, starting with 2014.

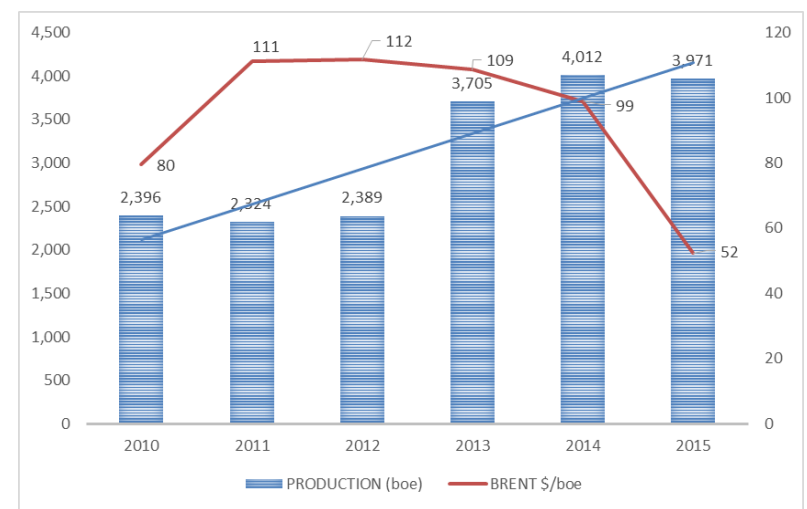

Figure 2: Crude Oil Production (Th boe/day) vs BRENT (\$/boe)

Source: Authors' own research results/contribution.

Rosneft increased its overall liquid production investing in exploration and exploitation of new blocks in Siberia and in the Arctic region. Despite crude oil price fall at the end of 2014, Rosneft kept the expenditures in exploration and production at a high level. The investment capacity comes from the difference between the RUB/USD exchange rate. Russian Ruble value started to decline in the same period as the oil price October/November 2014, as it is seen in the Table 1.

Table 1. Rubble USD Dollars exchange rate

\begin{tabular}{|c|c|}
\hline Date & RUB / 1 USD \\
\hline 14-Sep & 39.6 \\
\hline 14-Oct & 43.0 \\
\hline 14-Nov & 50.4 \\
\hline 14-Dec & 55.9 \\
\hline 15-Jan & 68.8 \\
\hline 15-Feb & 61.6 \\
\hline 15-Mar & 58.2 \\
\hline
\end{tabular}


Source: Authors' own research results/contribution.

The exchange rate increased by $88 \%$ in only 6 months, starting with Sept. 2014 and up until March 2015. Rosneft's main assets are located in the Russian Federation and the investments are calculated and executed in Russian Rubles, while the oil trading occurs in USD, in accordance with market indexes.

Capital expenditures in the exploration and production sector continue their growing trend for the analyzed period, recording an average increase of $16 \%$ per year. The company overall Net Profit climbed up until 2013 and has had 1 pp reduction in 2014. The Net Profit reduction comes from changes in taxation for Mineral Exploration in the Russian Federation, which has been applied starting with $1^{\text {st }}$ of January 2014 , and from the changes in natural gas and gas condensate taxation, with effects starting on the $1^{\text {st }}$ of July 2014 .

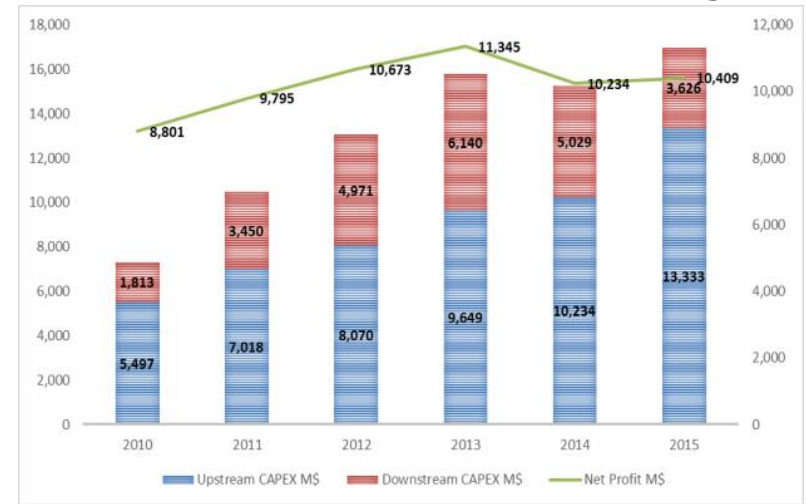

Figure 3: CAPEX (M\$) vs Net Profit (M\$)

Source: Authors' own research results/contribution.

Capital expenditures in exploration and production sector have a continuous growth trend for the whole analyzed period.

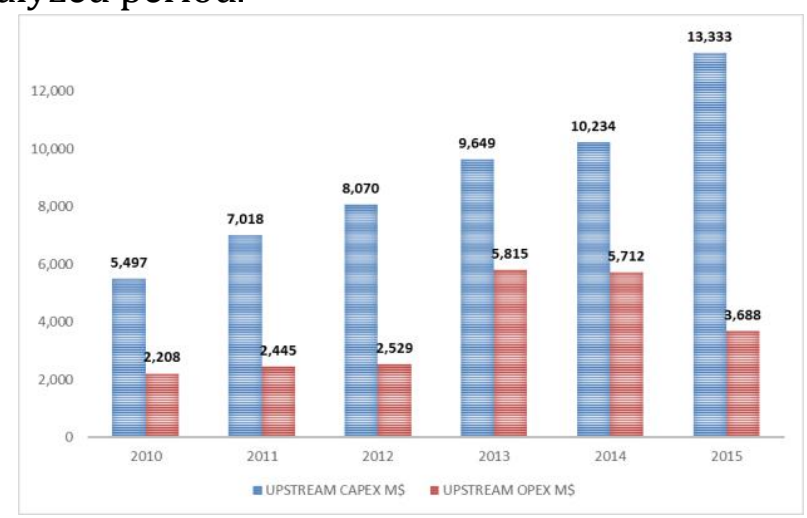

Figure 4: Upstrem CAPEX vs OPEX

Source: Authors' own research results/contribution.

The operational expenditures recorded a break from 2014 to 2015. The OPEX reduction comes as a result of oil price drop and as a measure of reduction the expenditures. The company revenue is very well balanced between upstream and downstream sectors. However, downstream revenues count more than $50 \%$ of total company revenues, in 2014 and 2015. 


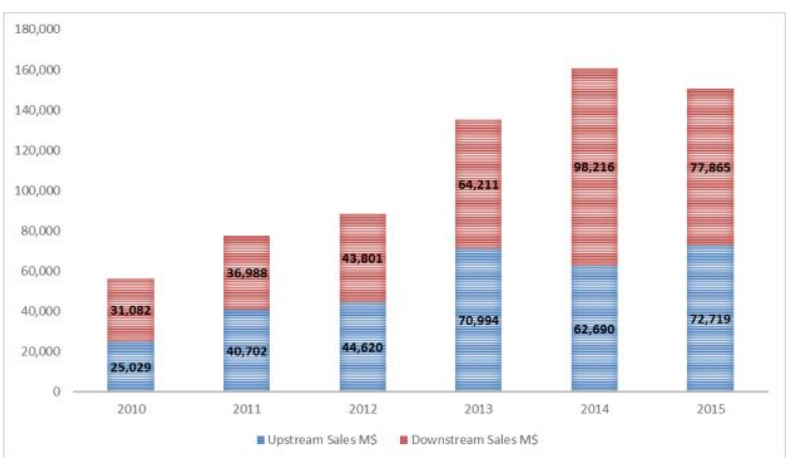

PICBE $\mid 13$

Figure 5: Upstream Sales (M\$) vs Downstream Sales (M\$)

Source: Authors' own research results/contribution.

The shift of the leading sector in company earnings is based on gross margin increase of downstream sales. The reduced OPEX and especially fixed costs, together with a reduced price of purchased the crude oil generated a big increase in commercial margin. The company reports a big EBITDA rise from 2014 to 2015(Rosneft, 2015).

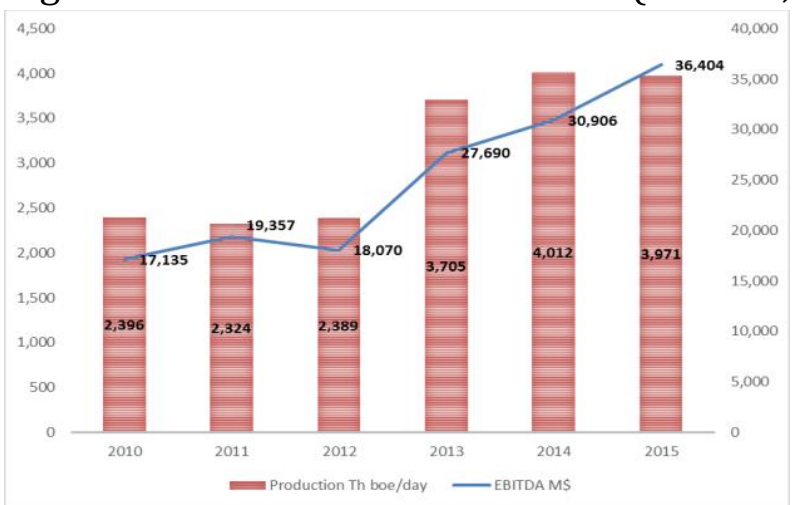

Figure 6: Crude Oil Production (Th boe/day) vs EBITDA (M\$)

Source: Authors' own research results/contribution.

\section{ExxonMobil}

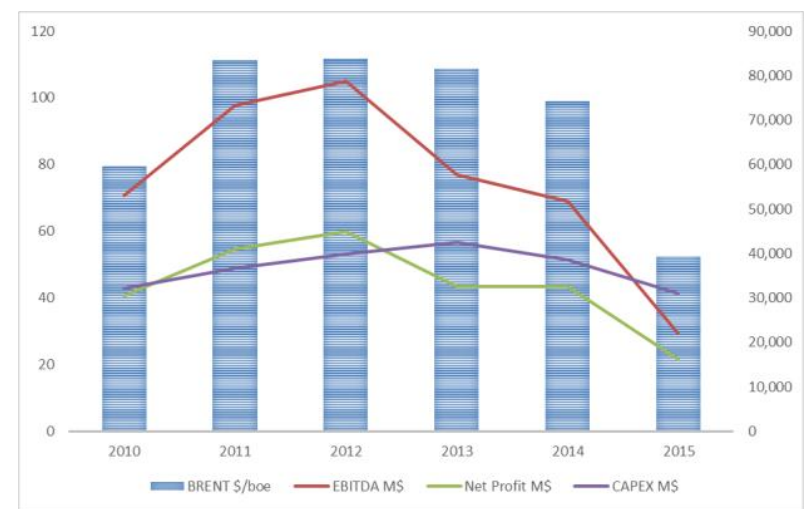

Figure 7: Main economic indicators vs Oil price

Source: Authors' own research results/contribution.

ExxonMobil is the biggest USA oil company, ranked on the second position worldwide (in terms of crude oil production in 2015). USA has promoted politics to bust the oil output of the country for the last decade. ExxonMobil kept a high level of capital investments in the 
exploration and production sector and this was one of the key reasons of why the earnings fell along with the oil price drop.

ExxonMobil records a continuous liquid production decrease rate from 2010 to 2014. The overall production was rejuvenated in 2015 only, which is in accordance with the overall USA tendency of increasing domestic oil production.

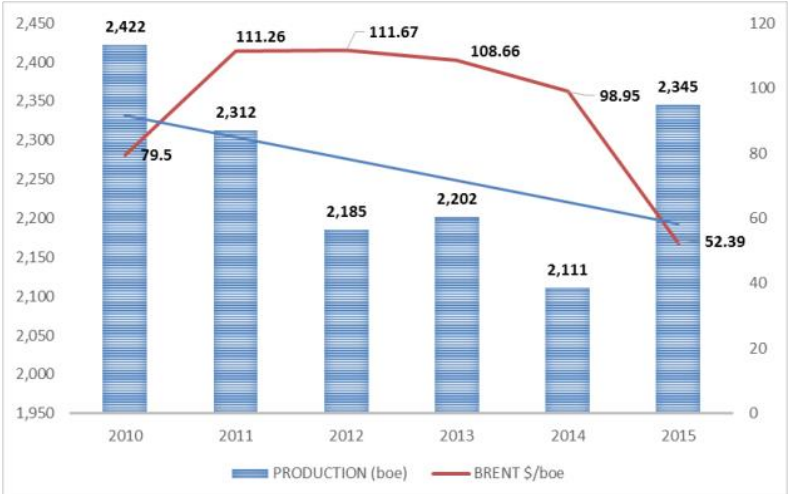

PICBE | 14

Figure 8: Crude Oil Production (Th boe/day) vs BRENT (\$/boe)

Source: Authors' own research results/contribution.

The capital expenditures in the exploration and production sector are decreasing, due to the reduction of the crude oil price. The net profit of the company follows the oil price trend, recording a fall of 50\% from 2014 to 2015. The decrease of the overall capital expenditures comes in contrast with the increasing investments in the downstream sector.

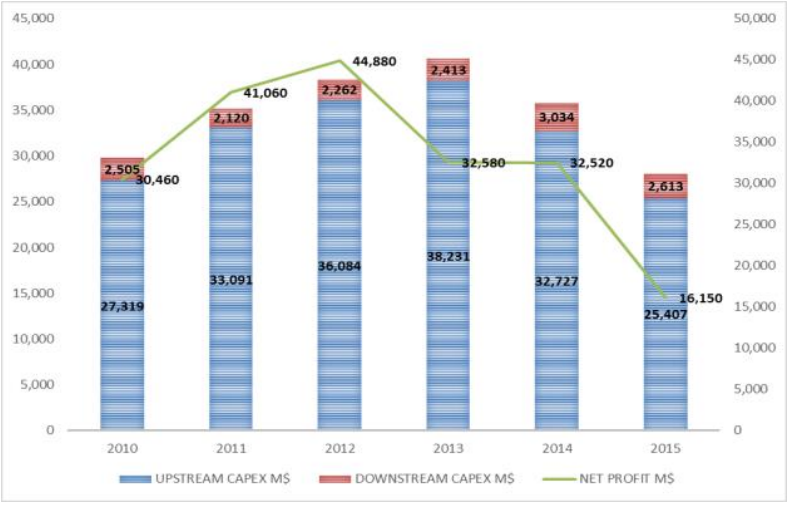

Figure 9: CAPEX (M\$) vs Net Profit (M\$)

Source: Authors' own research results/contribution.

As a result, the downstream steak of company earnings rises from $9 \%$ in 2014 to $40 \%$ in 2015. The cheap raw material and high price of final products helps the downstream sector recover from overall loss. Nevertheless, the company net earnings fell by $50 \%$ in 2015 , comparing to 2014 . 


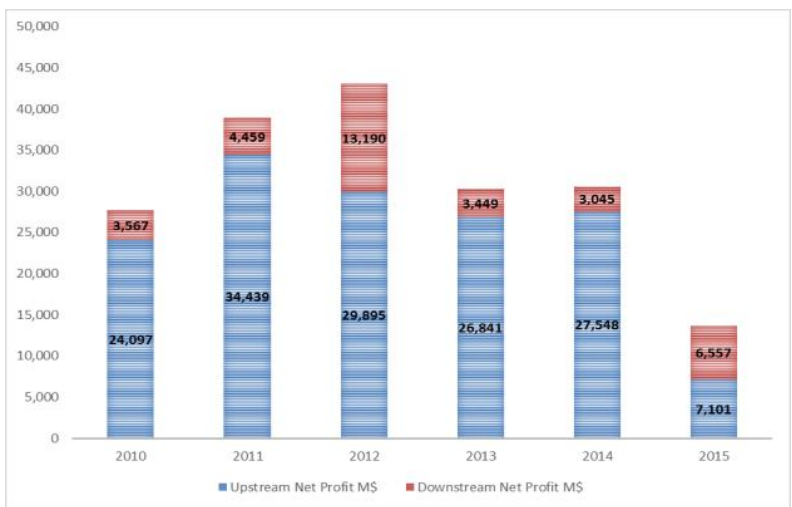

PICBE | 15

Figure 10: Upstream Net Profit (M\$) vs Downstream Net Profit (M\$)

Source: Authors' own research results/contribution.

The measures taken by the company, like crude oil production increase and expenditure reduction were not enough to avoid the EBITDA collapse in 2015.(ExxonMobil, 2015)

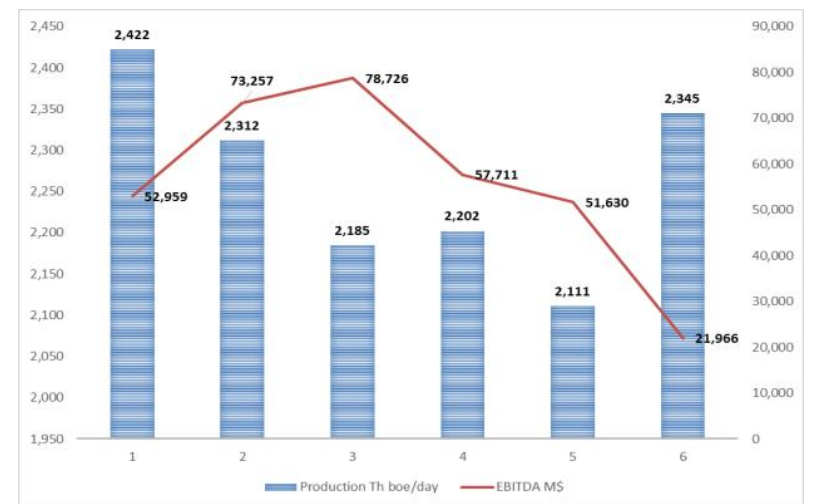

Figure 11: Crude Oil Production (Th boe/day) vs EBITDA (M\$)

Source: Authors' own research results/contribution.

\section{British Petroleum}

British Petroleum recent history is followed by the Gulf of Mexico oil spill in 2010. The company did not fully recover and still has to manage the large expenses required to cover the ecological disaster of Deep Water Horizon accident.

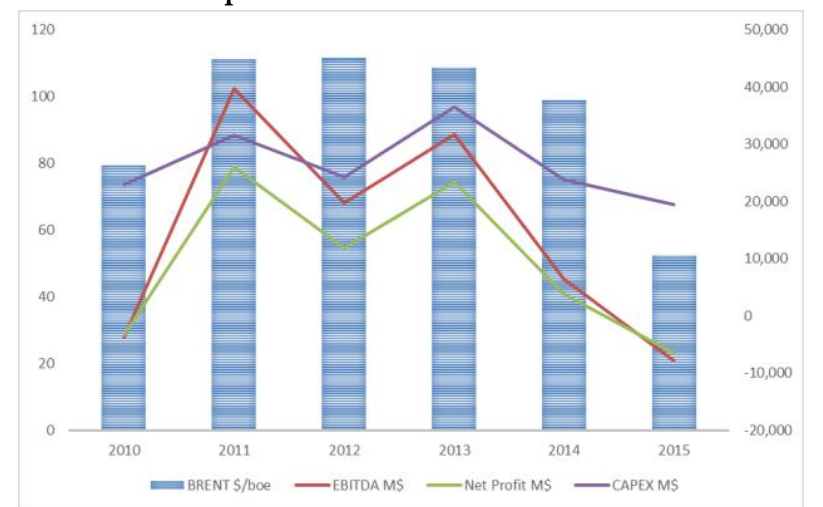

Figure 12: Main economic indicators vs Oil price

Source: Authors' own research results/contribution. 
The crude oil production is registering a constant decrease, with a small recovery in 2015, despite BRENT variation. Only in 2012 did BP sell around half of their upstream installations and pipelines, and around of one third of their wells.

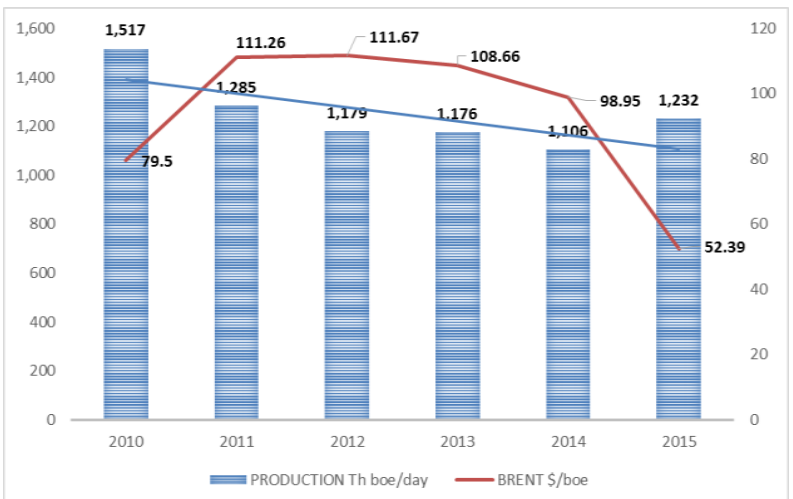

PICBE | 16

Figure 13: Crude Oil Production (Th boe/day) vs BRENT (\$/boe)

Source: Authors' own research results/contribution.

Capital expenditures in the exploration and production sector have grown continuously until 2015, while the downstream capital investments have been slowly sliding. The company earnings were very strong affected in 2010 as an effect of the Gulf of Mexico accident. The net profit varies in the next years, depending on the sums the company devotes with regard to the accident.

Starting with 2013, the company kicked off three new upstream projects in the Gulf of Mexico, Angola and Australia, three more following in the first months of 2014 in Azerbaijan and another 2 in the Gulf of Mexico.

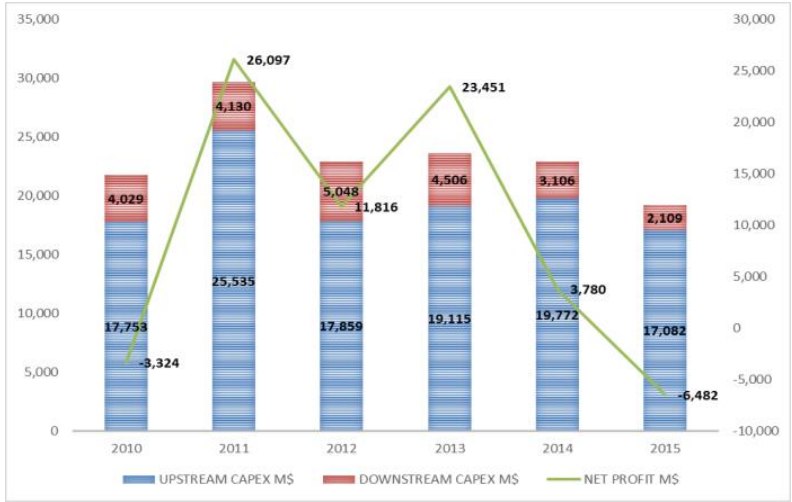

Figure 14: CAPEX (M\$) vs Net Profit (M\$)

Source: Authors' own research results/contribution.

Investments are cut down in downstream sector with a continue increase in upstream in order to rebuild the company from scratch, after big divestment program. Spending a lot on new upstream projects, the company starts big investments in 2013 and continue in 2014. These measures reduced the company cash flow indicators, which was already very weak, after contributions paid. However, all the investments in upstream did not help and the company reported that the reserves replacement ratio was only $61 \%$, in 2015, compared with 129\% in 2013. 
As a result of reducing the cash flow of the company, by big investment project, and reducing the crude oil price, in 2015, the company reports the biggest loss for the last 30 years. The net loss was $\$-6,5$ billion. After adjusting a net charge for non-operating items, which mainly related to the agreements in principle to settle federal, state, and the vast majority of local government claims arising from the 2010 Deepwater Horizon accident and impairment charges; and net favorable fair value accounting effects, underlying replacement cost (RC) profit for the year ended on the 31 $1^{\text {st }}$ of December 2015 was $\$ 5.9$ billion, a decrease of $\$ 6.2$ billion compared with 2014 . The reduction was mainly due to a significantly lower profit in upstream, partially offset by improved earnings from downstream.

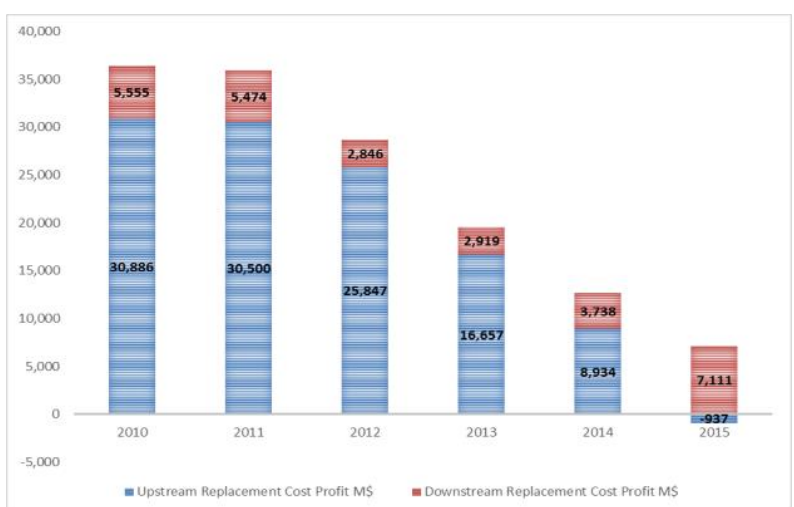

Figure 15: Upstream RC Profit (M\$) vs Downstream RC Profit (M\$)

Source: Authors' own research results/contribution.

Downstream is leading in terms of cost profit replacement in 2015. The low price for crude oil, together with high price of petroleum products, makes the shift between sectors in terms of earnings balanced. 2015 was a record year for BP's downstream, delivering $\$ 7.5$ billion of underlying pre-tax replacement cost of profit, demonstrating the benefit of being an integrated business.(BP, 2015)

\section{Royal Dutch Shell}

Shell was investing in upstream and downstream for years along up to 2014, when the company decided to moderate their growth ambitions and strives to improve their cash flow returns. Shell saw an overproduction of refinery products and a slowing trend of demand. They have taken the decision to start divestment in both business sectors.

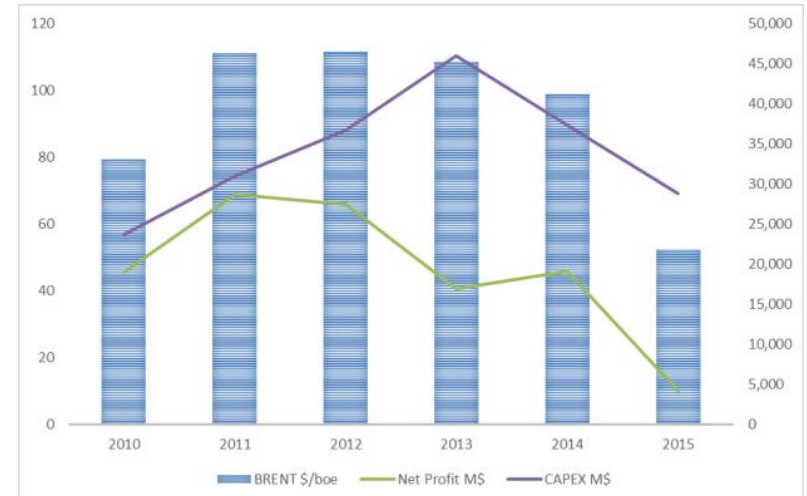

Figure 16: Main economic indicators vs Oil price

Source: Authors' own research results/contribution. 
The prudent investment strategy and delivery of some new projects around the world improved Shell earnings in 2014, compared to 2013. The prudent overall spending strategy continued into 2015, together with some big divestments in upstream. In 2015 Shell decided to pull out from Alaska project and to stop work on the Carmon Creek project in Canada and was charged, which contributed a lot to the upstream loss.

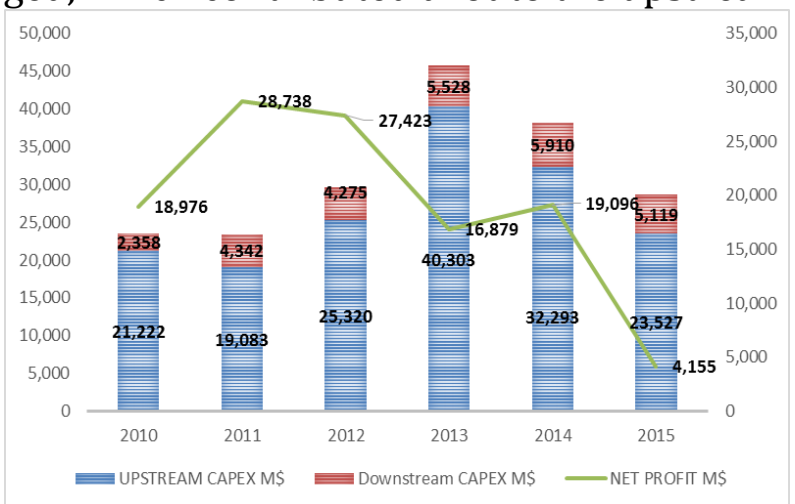

Figure 17: CAPEX (M\$) vs Net Profit (M\$)

Source: Authors' own research results/contribution.

The company reduced its operating expenses and capital investments by a combined $\$ 12.5$ billion in 2015, compared with 2014. Divestments exceeded the company target for the 2014-2015 period, amounting $\$ 20$ billion. Asset sales are part of the Shell strategy of reducing costs. On the other hand, the company started to invest aggressively in the downstream sector, like in Pernis Refinery in Netherlands and embark on a major expansion at their Geismar plant in the USA.

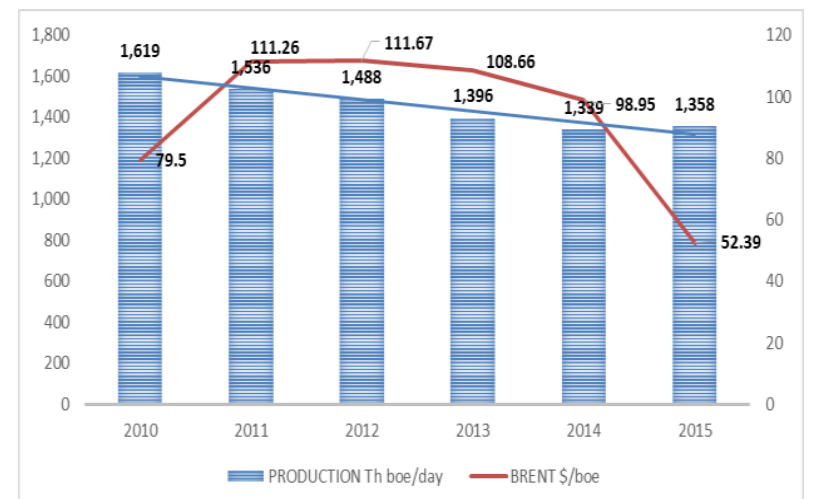

Figure 18: Crude Oil Production (Th boe/day) vs BRENT (\$/boe)

Source: Authors' own research results/contribution.

Shell has a continuous decline in production. The investments' stop in some developing upstream assets and selling some others was a result of production decline. In 2015 the company took the final investment decision to go ahead with the Appomattox deep water project in the Gulf of Mexico. The company wants to protect the growth prospects in a world where long term demand for energy will continue to rise. 


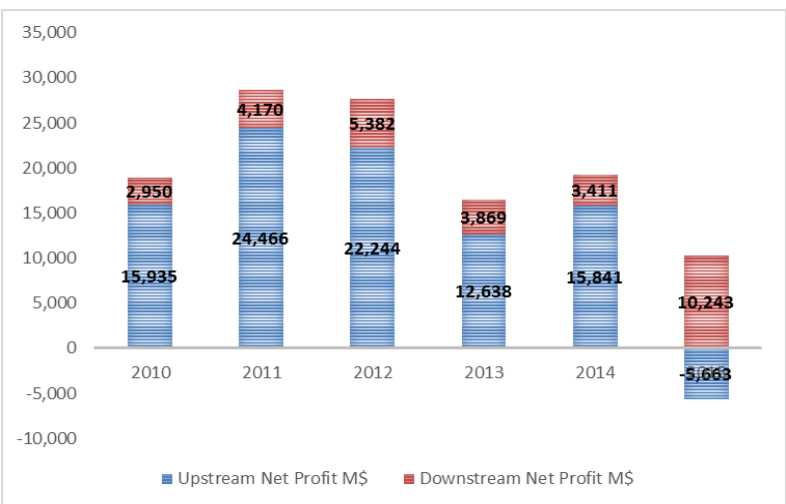

PICBE | 19

Figure 19: Upstream RC Profit (M\$) vs Downstream RC Profit (M\$)

Source: Authors' own research results/contribution.

As it was expected, the vertical integrated status of the company brought its results in 2015. The profit of the downstream sector expanded more than 3 times in 2015, comparing to 2014.(Royal Dutch Shell, 2015)

\section{Chevron}

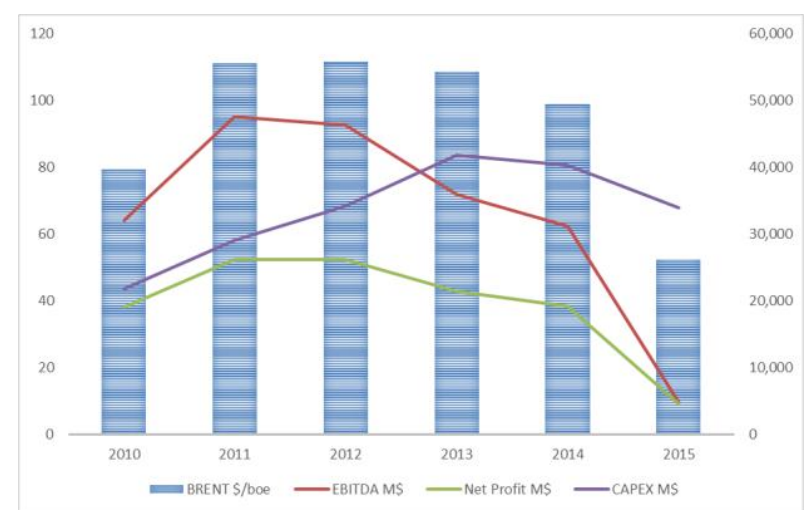

Figure 20: Main economic indicators vs Oil price

Source: Authors' own research results/contribution.

For the last 4 years' period, from 2012 to 2015, Chevron maintained high rates of capital investments in upstream as well as in downstream. In 2013 the exploratory and capital investments budget has a record pick of $\$ 36.7$ billion. It was reflected in exploring activities in new areas because of Chevron target to achieve 3.3 million boe per day in 2017, which means an increase of more than 20\% from 2010. In 2012, Chevron was anticipating 16 new upstream projects, with a Chevron share of investment of more than $\$ 1$ billion each, for the next 5 years. 


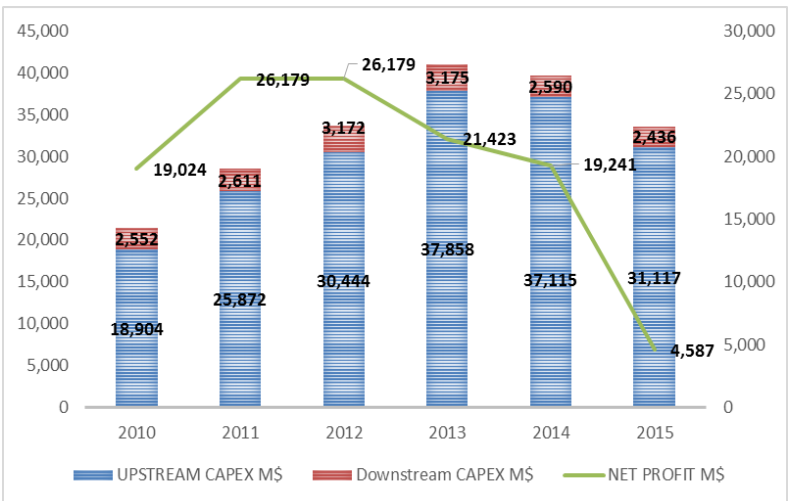

PICBE $\mid 20$

Figure 21: CAPEX (M\$) vs Net Profit (M\$)

Source: Authors' own research results/contribution.

The investment in the downstream segment was quite stable during the analyzed period. Chevron continued to invest in their refineries and chemical industry, mainly in the USA, as well in Singapore and in other locations, making Chevron the world's largest premium oil producer.

As expected, in 2015 the downstream segment took the leadership position in terms of origin of company earnings. This business maintained reliable operations, benefited from lower feedstock costs and achieved efficiency gained by the reshaping of the portfolio in the previous years.

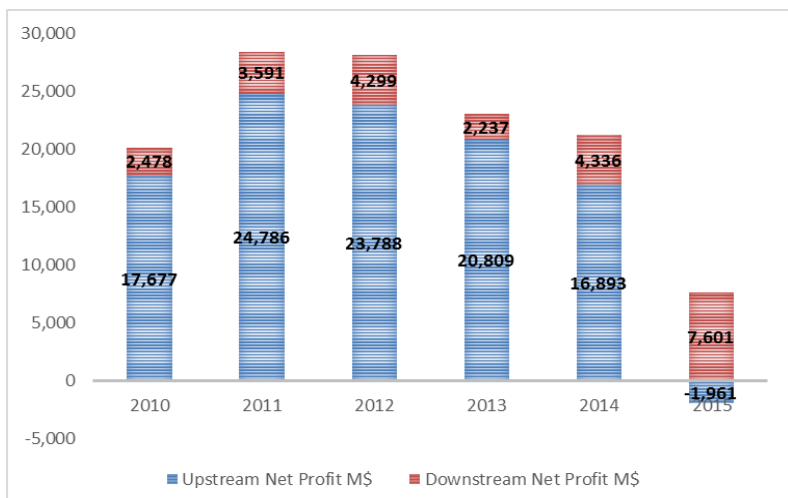

Figure 22: Upstream RC Profit (M\$) vs Downstream RC Profit (M\$)

Source: Authors' own research results/contribution.

In 2015, Chevron decided to reduce capital spending and aggressively cut costs while moving forward on developments that will grow production and cash flow for the future. The focus was in improving project execution and optimizing portfolio by massive divestments by assets that cannot compete for capital with other investments alternatives. 


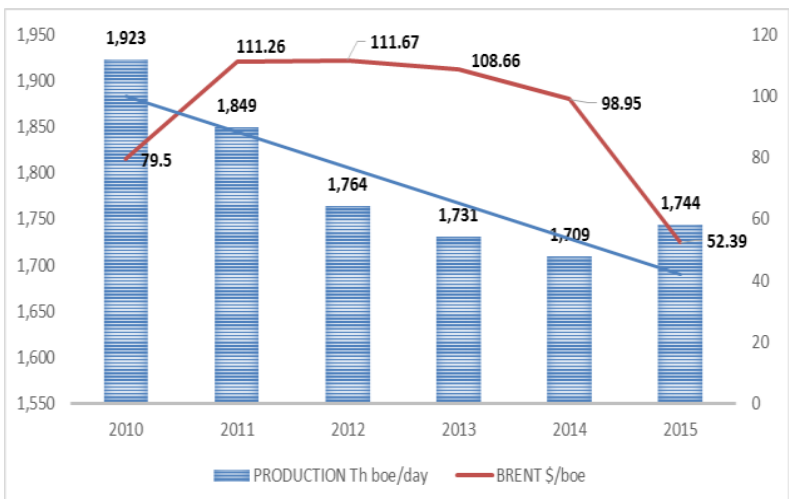

PICBE $\mid 21$

Figure 23: Crude Oil Production (Th boe/day) vs BRENT (\$/boe)

Source: Authors' own research results/contribution.

Despite the oil price continuous drop in 2015, Chevron has significantly increased the crude oil output, approximately to $107 \%$ comparing to 2014(Chevron, 2015).

\section{Conclusions}

During the last six years, the oil industry climbed up only to fall back down. The rise in the oil price registered at the beginning of the decade; together with an increased demand were factors that sent the wrong message to the market: namely that a period of growth was coming ahead. The crude oil price went over $\$ 100 /$ boe in only 3 years, after the previous crisis had come in 2008. The oil and gas companies, taking advantage of big revenues and earnings, started investing very aggressively in upstream projects, in order to secure their proven reserves and to increase the production level.

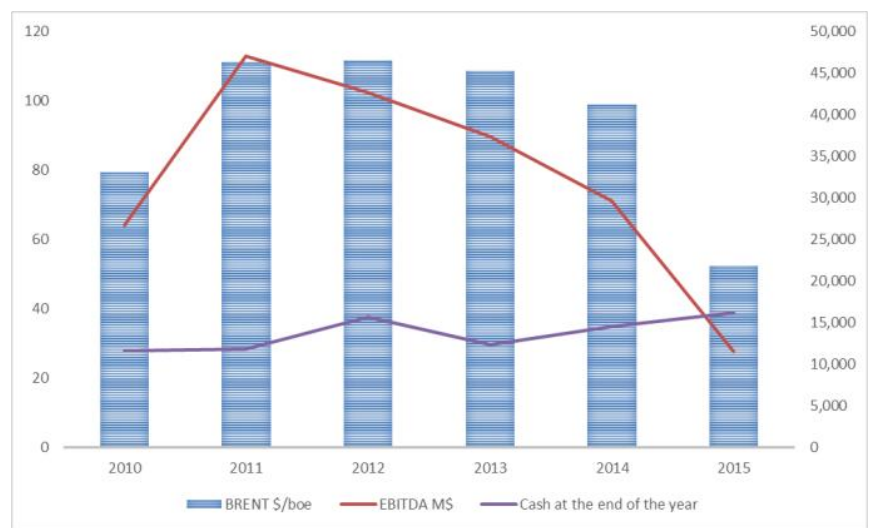

Figure 24: Main economic indicators vs Oil price

Source: Authors' own research results/contribution.

Excepting BP, which had to pay compensations, according to Deep Water Horizon convictions, most of the oil supermajors started developing the upstream assets. The capital investments increased significantly in 2012 and 2013, indeed reducing the earning indicators of the companies, as well as the cash flow.

The oil price dropped by $47 \%$ in 2015 benchmarking to 2014 and by 53\% comparing to 2012. Thus the revenues slid congruent and the main economic indicators, such as EBIDTA loss 61\% comparing to 2014 and $73 \%$ comparing to 2012. 
The end of 2014 found most of the oil majors very optimistic regarding the dynamic of the market and securing their investment plans. However, the oil price slid very quickly back to $\$ 50 /$ boe and even lower at the beginning of 2016 .

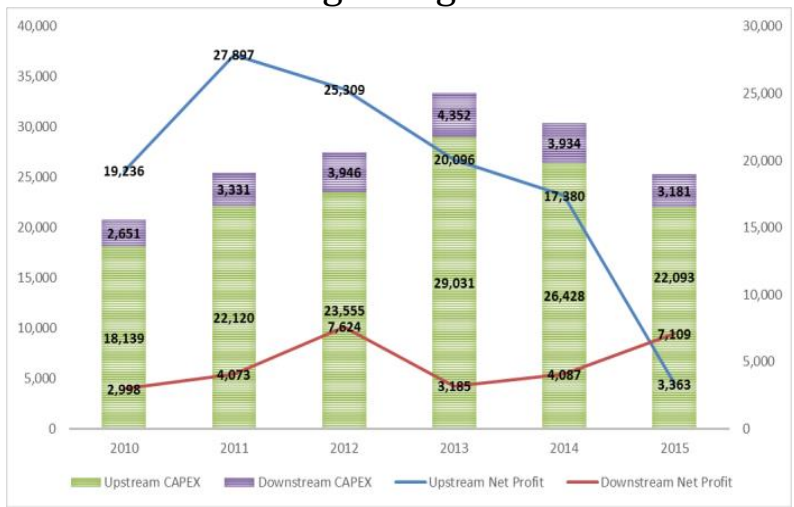

PICBE $\mid 22$

Figure 25: CAPEX (M\$) vs Net Profit (M\$)

Source: Authors' own research results/contribution.

Most of the oil majors reduced their investments and started aggressive divestment programs in upstream, in 2015. Meanwhile, the downstream sector started taking the advantages of cheap crude oil. Nevertheless, the downstream did not have the potential to cover the loss of the upstream. Average available Cash flow at the end of the year 2015 represents $\sim 112 \%$ comparing to 2014 and $\sim 104 \%$ comparing to 2012. Aggressive divestments programs as well as reduction in spending saved the cash flow balances of the companies. The Capital expenditures in 2015 was by $\sim 16 \%$ less comparing to 2014 and $\sim 29 \%$ lower than 2013. However, the capital investments in 2015 were by $\sim 9 \%$ bigger than it was in 2012.

Companies continued to take the advantage of the previous year's investments and have had an increasing trend of crude production. The increasing supply and flatted demand accelerated the price drop.

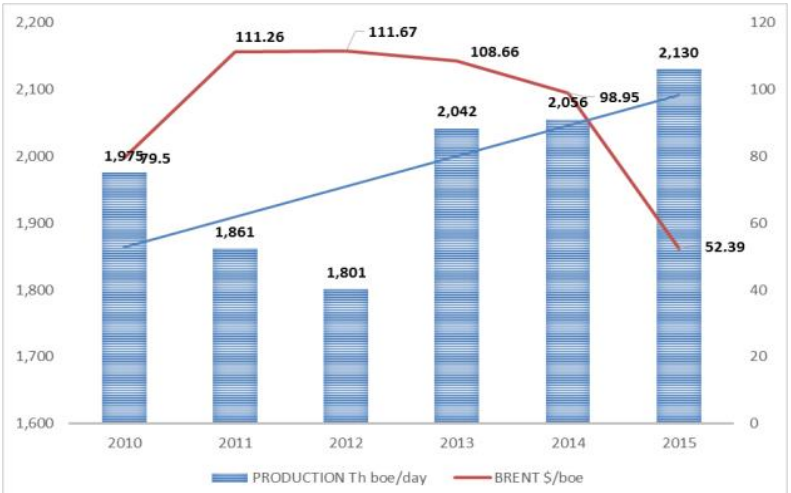

Figure 26: Crude Oil Production (Th boe/day) vs BRENT (\$/boe)

Source: Authors' own research results/contribution.

The competition between oil majors and big NOCs, mainly OPEC countries, was fueling the increase of production. The average production amount grew from $1.8 \mathrm{Th}$. boe/day in 2012 to $2.1 \mathrm{Th}$. boe/day in 2015. Production level of 2015 was by $\sim 104 \%$ comparing to 2014 and $118 \%$ comparing to 2012 . 
In terms of crude oil price, the average of the year 2012 was $\$ 111.67 /$ boe, while the average of 2015 was only $\$ 52.39 /$ boe - a difference of almost $\$ 60 /$ boe. The capital investments fell by 30\%, from $\$ 36.7$ billion in 2013 to $\$ 26.1$ billion in 2015 .

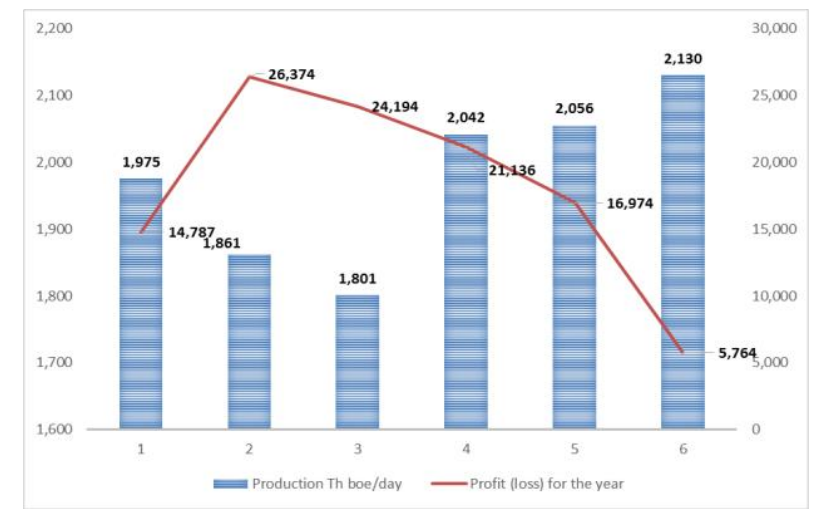

Figure 26: Crude Oil Production (Th boe/day) vs Net Profit (\$)

Source: Authors' own research results/contribution.

The average financial results of the analyzed companies went from $\$ 26.4$ billion in 2011 to $\$ 5.7$ billion in 2015. A decrease of $78 \%$ in earnings in 5 years can be explained by the reduction of oil price, while the capital expenditures recorded a moderate reduction, much less than the production growth. The stable trend of the available cash flow the end of the year proves the financial politics of the oil majors and leaves enough potential for a new growing wave of the oil and gas upstream industry, as well as by big divestments programs, which brought big cash stakes in companies accounts. The divestments programs should diminish the next period, due to the necessity to maintain the production level. Therefore, companies should adopt a much more constructive strategy in order to revive the earnings indicators and to maintain the cash flow indicators.

The next period growing forecasted energy demand needs to be backup by an investments and production increase. The $\sim \$ 60$ /boe could be achieved and maintained if the production growth tendency will be very close to market demand. The OPEC and nonOPEC countries agreement of production reduction could provoke a short turn and demand could run bigger than supply by 2017. However, oil supermajors announce the investments reduction in high costs fields of the North Sea and other similar regions and start to invest in low costs, new fields in Siberia and other regions. The time gap, before the new field's production will cover the market demand while the old fields will decrease the daily production output, could bring new turbulence in energy supply. The same as, oil supermajors could register a short period reduction in cash flow due to reduction in production and big investments programs in new production fields.

\section{References}

Helman, C. (2016). The World's Biggest Oil Companies, The World's 25 Biggest Oil Companies: forbes.com (https://www.forbes.com/sites/christopherhelman/2012/07/16/theworlds-25-biggest-oil-companies/\#70ed1d9360ca). 
Rosneft. (2015; 2014; 2013; 2012; 2011; 2010). Annual Report.

ExxonMobil. (2015; 2014; 2013; 2012; 2011; 2010). Annual Report.

British Petroleum. (2015; 2014; 2013; 2012; 2011; 2010). Annual Report.

Royal Dutch Shell. (2015; 2014; 2013; 2012; 2011; 2010). Annual Report.

PICBE $\mid 24$

Chevron. (2015; 2014; 2013; 2012; 2011; 2010). Annual Report. 